\title{
Citric Acid-modified Starch as an Environmentally Friendly Binder for Wood Composite Making
}

\author{
Mohd Hazim Mohamad Amini, ${ }^{\mathrm{a}, *}$ Rokiah Hashim, ${ }^{\mathrm{b}}$ Nurul Syuhada Sulaiman, \\ Mazlan Mohamed, ${ }^{\mathrm{a}}$ and Othman Sulaiman ${ }^{\mathrm{b}}$ \\ Conventional formaldehyde-based wood binders for composites have been \\ reported as hazardous to humans after prolonged exposure to released \\ fumes. Therefore, this research was conducted to evaluate suitability of citric \\ acid-modified corn starch as binder for wood composites. Corn starch was \\ gelatinized before it was reacted with citric acid, mixed with wood particles, \\ pre-pressed, and finally hot-pressed before characterization and evaluation. \\ Through Fourier transform infrared analysis, ester groups were detected at \\ $1736.8 \mathrm{~cm}^{-1}$, which was characteristic for starch modified with citric acid. \\ Bending test results on citric acid modified corn starch wood composites \\ showed $16.8 \mathrm{~N} / \mathrm{mm}^{2}$ and $4020 \mathrm{~N} / \mathrm{mm}^{2}$ for modulus of rupture and modulus of \\ elasticity, respectively. Addition of $2 \%$ urea-formaldehyde increased these \\ numbers to $17.9 \mathrm{~N} / \mathrm{mm}^{2}$ and $5190 \mathrm{~N} / \mathrm{mm}^{2}$, respectively. Internal bonding \\ additionally increased from $0.88 \mathrm{~N} / \mathrm{mm}^{2}$ to $0.95 \mathrm{~N} / \mathrm{mm}^{2}$. All test specimens \\ passed mechanical strength requirements by JIS A 5908 (2003). Based on \\ the demand specification for the final usage of the wood composite, it can be \\ concluded that citric acid modified starch is a possible successful choice as \\ the adhesive, with or without additional urea formaldehyde resin.
}

Keywords: Starch; Citric acid; Wood; Composite; Binder; Environmentally friendly; Mechanical strength; Fungal

Contact information: a: Faculty of Bio-Engineering and Technology, Universiti Malaysia Kelantan, 17600 Jeli, Kelantan, Malaysia; b: Division of Bioresource, Paper and Coatings Technology, School of Industrial Technology, Universiti Sains Malaysia, 11800 Penang, Malaysia;

* Corresponding author: hazimamini@gmail.com

\section{INTRODUCTION}

An adhesive or glue is a substance capable of holding at least two surfaces together in a permanent and robust manner. Related to adhesives are sealants, which are substances capable of attaching to at least two surfaces, filling space between them to provide a barrier or protective coating. There are many available types of adhesives based on their chemical structure and properties. Some classes of adhesives are protein adhesives, animal glues, carbohydrate polymers as adhesives, natural rubber-based adhesives, elastomeric adhesives, polysulfide sealants and adhesives, phenolic resin adhesives, natural phenolic adhesives (tannin and lignin), resorcinol adhesives, furan-based adhesives, ureaformaldehyde adhesives, melamine-formaldehyde adhesives, isocyanate wood binders, polyurethane adhesives, polyvinyl and ethylene-vinyl acetates, unsaturated polyester adhesives, hot-melt adhesives, reactive acrylic adhesives, silicone adhesives and sealants, epoxy resin adhesives, pressure-sensitive adhesives, and electrically conductive adhesives (Pizzi and Mittal 2003).

Carbohydrate polymers exist in polysaccharide-forming plants. For adhesive production, three types of carbohydrate polymers, namely cellulose, starch, and gum, are 
used. Vast sources can be used to obtain these materials, such that they have high possibility to be fully utilized as adhesives, while petroleum-derived polymeric materials can be expected to become scarce and their prices to increase. Starch is a substance that contains mainly two polysaccharides, amylose and amylopectin. Amylose is a straight chain of $\alpha-(1 \rightarrow 4)$ linked glucan, while amylopectin consists of $\alpha-(1 \rightarrow 4)$ linked glucan with $4.2 \%$ to $5.9 \%$ of $\alpha-(1 \rightarrow 6)$ branch linkages. The proportion of starch amylose to amylopectin varies according to their source (Robyt 2008). Starch granules are insoluble in water. To make use of starch, the first step required is the gelatinization process. Gelatinization can be completed by heating starch in hot water or by using chemical means such as high-concentration salts, acids, or alkalis. The gelatinization process increases motion of molecules in the granule before breaking hydrogen and hydrophobic bonds, thereby making starch soluble and ready for modification. Modification is a must, as bonds formed by carbohydrate polymer adhesives are generally sensitive to water.

This work evaluated the performance of citric acid-modified corn starch. Previously, different modifications of starch as binder for wood composites have been carried out by several researchers. The modification includes glutardialdehyde-modified starch (Amini et al. 2013), epichlorohydrin-modified starch (Sulaiman et al. 2018), citric acid-modified corn starch (Amini et al. 2012), and carboxymethyl starch (Selamat et al. 2014). As starch is a naturally water absorbent, the effect of urea-formaldehyde addition on properties of wood composite was also being tested. Corn starch was chemically modified and then mixed with rubberwood particles before pressing. Hot-pressing was performed to cure binder to form the final composite. Modified corn starch was used to reduce urea-formaldehyde in binder formulation, which was found to release carcinogenic fumes in service. A small amount of urea formaldehyde was used to balanced between the need to produce more water resistant and remained as an environmentally friendly wood composite.

\section{EXPERIMENTAL}

\section{Materials}

Raw material and chemicals were obtained from a local supplier. Corn starch was purchased from Sigma-Aldrich (St. Louis, MO, USA), and powdered citric acid was obtained from Merck Chemical Company (Darmstadt, Germany). Urea-formaldehyde with viscosity of $150 \mathrm{cP}$ and solids content of $49.5 \%$ was obtained as complimentary from Momento Specialty Chemical (Prai, Penang, Malaysia). Rubberwood particles were obtained from Heveaboard Sdn Bhd (Seremban, Malaysia). Wood particles were screened through $450 \mu \mathrm{m}$ mesh to remove fines that can affect the strength of particleboards.

\section{Preparation of binder}

Three types of binder were prepared, which were citric acid-modified corn starch (CAMCS), citric acid-modified corn starch with 2\% urea-formaldehyde (CAMCSUF), and urea-formaldehyde (UF) as a control sample. A corn starch powder sample of $50 \mathrm{~g}$ was dissolved in a beaker of $250 \mathrm{~mL}$ of distilled water and heated to $50{ }^{\circ} \mathrm{C}$ inside an electronically controlled water bath. The method for etherification of starch using citric acid was adopted from Reddy and Yang (2010). A sample of $10 \mathrm{~g}$ of citric acid was added slowly to dissolved corn starch solution with sodium hypophosphite added as a catalyst at $50 \% \mathrm{w} / \mathrm{w}$ on weight of citric acid used. The mixed solution was heated up to $90{ }^{\circ} \mathrm{C}$ for 
starch to gelatinize and react to complete the esterification process. Stirring was continued until the mixture became sticky. Corn starch modified with citric acid was used in thick liquid form for composite making.

\section{Wood composite making}

To make wood composite panels, rubberwood particles were hand-mixed with $13 \%$ citric acid-modified corn starch and $2 \%$ urea-formaldehyde before they were poured and evenly distributed inside a stainless steel mould with dimensions of $210 \mathrm{~mm} \times 210 \mathrm{~mm} \times$ $5 \mathrm{~mm}$. Mixed components were cold-pressed to form a mat and then hot-pressed (Model 3891 Auto "M", Carver, Inc., Wabash, IN) to cure under a pressure of $5 \mathrm{MPa}$ at a temperature of $165^{\circ} \mathrm{C}$ for $20 \mathrm{~min}$. Panels were cooled down and sandwiched between steel plates to ensure even moisture release and prevent panel warping. Panels were made at target density levels of $0.60 \mathrm{~g} / \mathrm{cm}^{3}, 0.70 \mathrm{~g} / \mathrm{cm}^{3}$, and $0.80 \mathrm{~g} / \mathrm{cm}^{3}$, then conditioned in a conditioning room with a temperature of $25{ }^{\circ} \mathrm{C}$ and a relative humidity of $65 \%$ for two weeks. Panels were then ready for testing.

\section{Methods}

\section{Characterization of wood composite}

To study changes in surface functional groups, Fourier transform infrared (FT-IR) spectroscopy analysis was performed (Muyonga et al. 2004; Amini et al. 2015) using pelletized samples. Approximately $100 \mathrm{mg}$ of potassium bromide (KBr) was mixed with 2 $\mathrm{mg}$ of ground sample before they were cold-pressed in a round flat mould. Prepared samples were scanned using a Thermo Scientific Nicolet 6700 FT-IR spectrometer (Thermo Fisher Scientific, Waltham, MA, USA) between the wavenumber range of 4000 $\mathrm{cm}^{-1}$ to $470 \mathrm{~cm}^{-1}$.

X-ray diffraction patterns were generated using a Shimadzu XRD-6000 diffractometer (Shimadzu Corporation, Kyoto, Japan). Powdered samples were analyzed for their crystallinity by step scan measurements using X-rays $(\mathrm{Cu}-\mathrm{Ka})$ at $40 \mathrm{kV}$ and 40 $\mathrm{mA}$. Scanning of $2 \theta$ was performed from $10.0^{\circ}$ to $40.0^{\circ}$ with scanning speeds set at $0.02 \%$ min and $2 \%$ min (Hermawan et al. 2002). The crystallinity index $\left(C_{\text {Ir }}\right)$ was determined by Eq. 1,

$$
C_{I r}(\%)=\frac{\left(I_{200}-I_{a m}\right)}{I_{200}} \times 100
$$

where $I_{200}$ is the peak intensity corresponding to crystalline and $I_{\mathrm{am}}$ is the peak intensity of amorphous fraction. The $I_{002}$ was measured at $22.8^{\circ}$ and $I_{\mathrm{am}}$ at $18.0^{\circ}$ (Liimatainen et al. 2012).

Thermogravimetry and differential scanning calorimetry analysis were performed to assess thermal behavior of prepared wood composites. Shimadzu TGA-50 (Shimadzu Corporation, Kyoto, Japan) was used for thermogravimetry analysis using $10 \mathrm{mg}$ of powdered sample. The sample was heated from $30{ }^{\circ} \mathrm{C}$ to $700{ }^{\circ} \mathrm{C}$ at a heating rate of 10 ${ }^{\circ} \mathrm{C} / \mathrm{min}$ with nitrogen flow maintained at $20 \mathrm{~mL} / \mathrm{min}$ to create an inert atmosphere. Differential scanning calorimetry was performed from $20^{\circ} \mathrm{C}$ to $120^{\circ} \mathrm{C}$ at a heating rate of $10{ }^{\circ} \mathrm{C} / \mathrm{min}$ using a PerkinElmer DSC 4000 differential scanning calorimeter (PerkinElmer Inc., Waltham, MA, USA). 


\section{Testing of Wood Composites}

Moisture content analysis was performed using an oven-drying method along with the study of water absorption and thickness swelling after immersion in water and exposure to different relative humidity $(35 \%, 55 \%, 75 \%$, and $95 \%)$. Flexural and internal bonding strength was tested according to JIS A 5908 (JIS A 5908 2003) using an INSTRON tensile strength tester machine (Model 5582 ; Instron, Norwood, MA, USA). Fungal resistance of wood composites was tested using Formitopsis palustris, Schizophyllum commune, Trametes versicolor, and Pycnoporus sangineus. Breeds of fungi used for testing were obtained from the School of Biology, Universiti Sains Malaysia (Penang, Malaysia). Wood composites panel were cut into $25 \mathrm{~mm} \times 25 \mathrm{~mm}$ squares and laid on sterilized soil inside a clean bottle. Fungal agar plug was inoculated onto samples before incubation for six months. Final weight was taken, and degree of fungal attack was calculated using Eq. 2,

$$
\text { Degree of fungal attack }(\%)=\frac{m_{i}-m_{f}}{m_{i}} \times 100
$$

where $m_{\mathrm{i}}$ is initial weight $(\mathrm{g})$ of conditioned specimens before fungal exposure and $m_{\mathrm{f}}$ is final weight $(\mathrm{g})$ of conditioned specimens after fungal exposure.

All of the data obtained were processed for analysis of variance, ANOVA using the SPSS statistical software (SPSS for Windows, version 20.0, SPSS Inc., United States).

\section{RESULTS AND DISCUSSION}

\section{Characterization of Wood Composites}

FT-IR analysis

Figure 1 shows the infrared spectra of wood composites made using modified corn starches, modified corn starches with UF resin, and UF only. Wood composite made using CAMCS showed the O-H group at $2918.0 \mathrm{~cm}^{-1}, 1374.3 \mathrm{~cm}^{-1}$, and $1332.6 \mathrm{~cm}^{-1}$. Meanwhile, ester group was detected by a peak at $1736.8 \mathrm{~cm}^{-1}$.

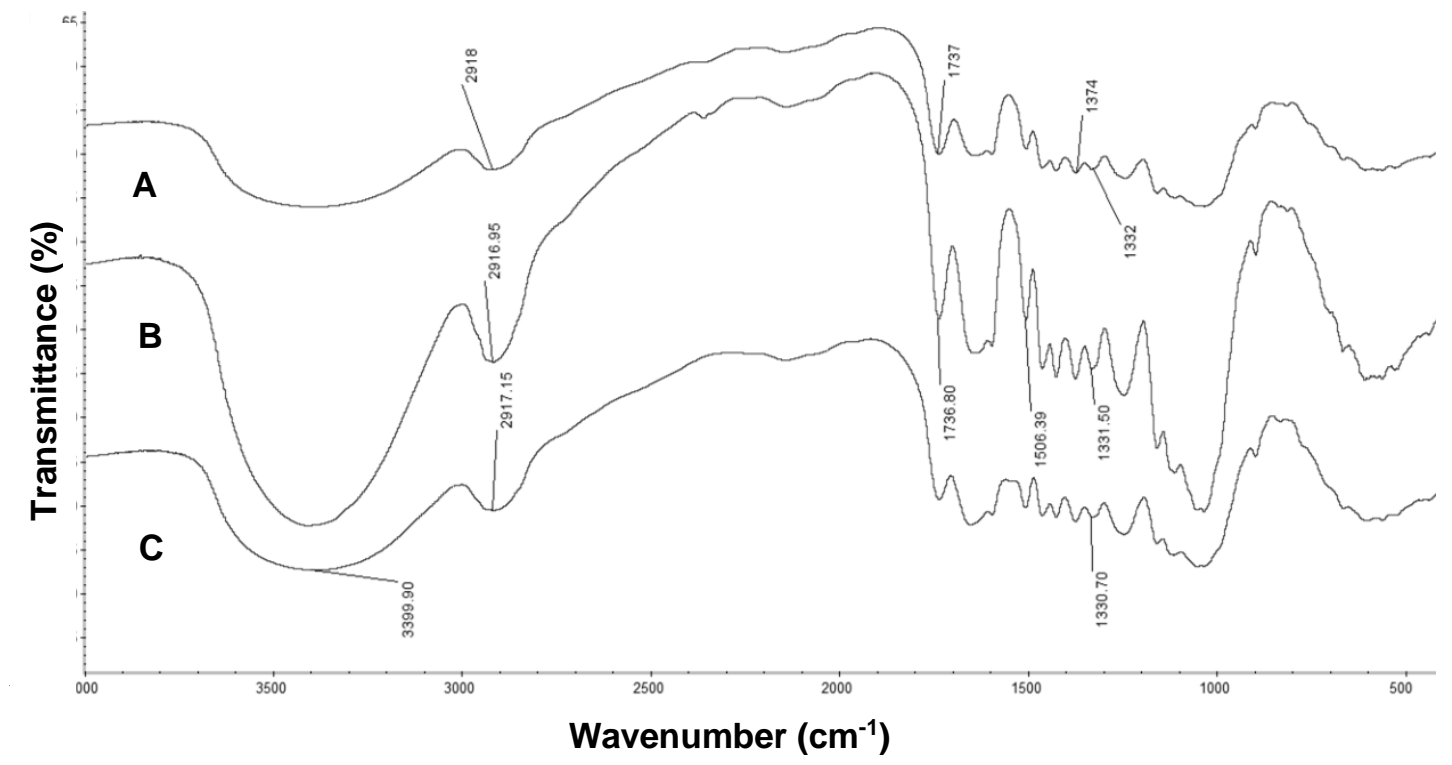

Fig. 1. FT-IR spectra for CAMCS wood composite (A), CAMCSUF wood composite (B), and UF wood composite $(\mathrm{C})$ 
The ester group was detected (Reddy and Yang 2010), which is characteristic for starch modified with citric acid (Ma et al. 2009; Wilpiszewska and Czech 2014), as shown by the reaction mechanism in Fig. 2. Wood composite made using citric acid modified corn starch with $2 \%$ urea formaldehyde showed the O-H group at $2917 \mathrm{~cm}^{-1}$ and $1332 \mathrm{~cm}^{-1}$. The ester group was detected at $1736.8 \mathrm{~cm}^{-1}$. Peaks at 3373.4, 1596.9, and $1506.4 \mathrm{~cm}^{-1}$ showed the presence of urea-formaldehyde as $\mathrm{N}-\mathrm{H}$ stretching vibrations. The control, urea formaldehyde bonded wood composite showed O-H group peaks at 2917.2 and $1330.7 \mathrm{~cm}^{-}$ , while N-H stretching vibrations were found at $3399.9 \mathrm{~cm}^{-1}$.
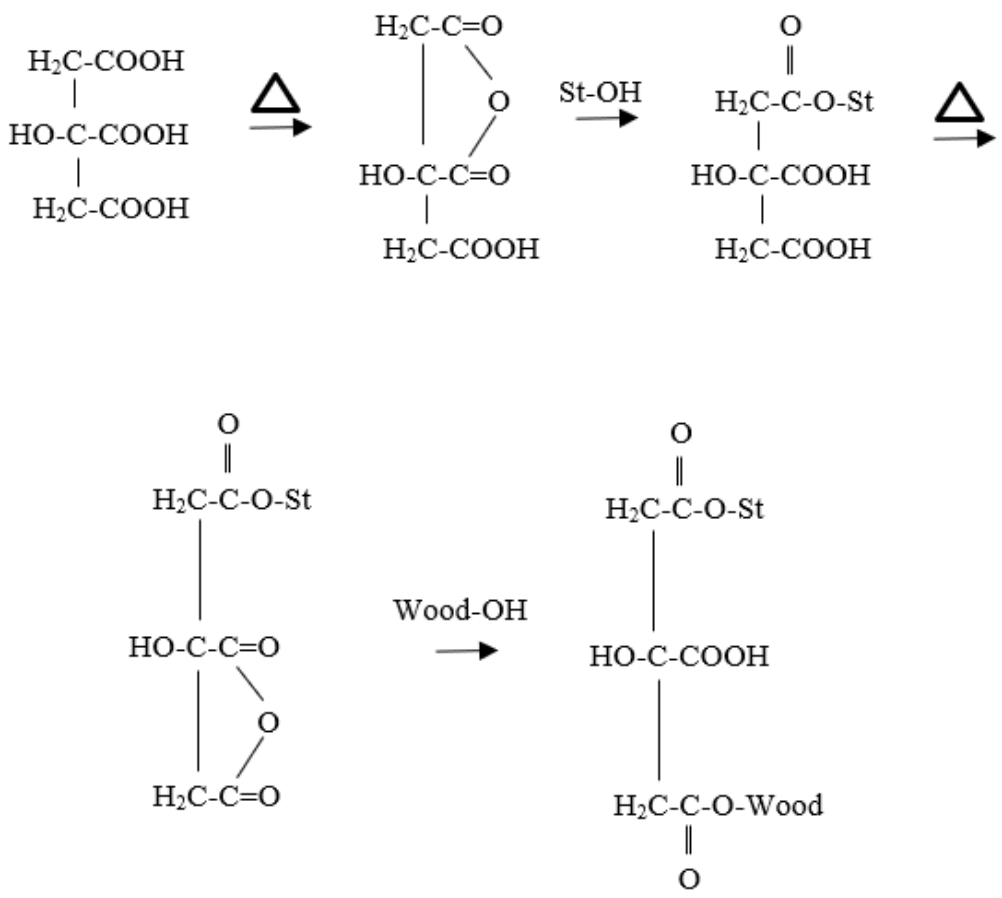

Fig. 2. Reaction of citric acid-modified starch with wood particle

\section{Thermal characterization}

Figure 3 shows thermogravimetry and derivative thermogravimetry curves of wood composites made using CAMCS, CAMCSUF, and UF as binder. The early stage of weight reductions for all samples was caused by evaporation of moisture, where there was a faster rate of weight reduction in the area near $100{ }^{\circ} \mathrm{C}$. Thermogravimetry curves showed $64.8 \%$ weight reduction for wood composite made using CAMCS between temperatures of 200 ${ }^{\circ} \mathrm{C}$ and $500{ }^{\circ} \mathrm{C}$.

The highest decomposition rate was $0.16 \% / \mathrm{min}$ at $354.5{ }^{\circ} \mathrm{C}$ for wood composites made using CAMCS. Later, the residue of samples was $23.74 \%$ at $700{ }^{\circ} \mathrm{C}$ for wood composite made using CAMCS. Derivative thermogravimetry curves showed highest percentages of decomposition of $0.13 \% / \mathrm{min}$ at $388.0{ }^{\circ} \mathrm{C}$ and $0.18 \% / \mathrm{min}$ at $341.4{ }^{\circ} \mathrm{C}$ for wood composites made using CAMCSUF and UF, respectively. At the end of heating at $700{ }^{\circ} \mathrm{C}$, remaining residues were similar for wood composites made using CAMCSUF and UF, which is $20.1 \%$. The hemicellulose and cellulose decomposition took place between $200{ }^{\circ} \mathrm{C}$ and $380{ }^{\circ} \mathrm{C}$, while lignin decomposition showed a wider range between $180{ }^{\circ} \mathrm{C}$ and $900{ }^{\circ} \mathrm{C}$ (Gašparovič et al. 2010). Results indicated that a wood composite made using CAMCS showed higher thermal stability throughout the temperature sweep. 


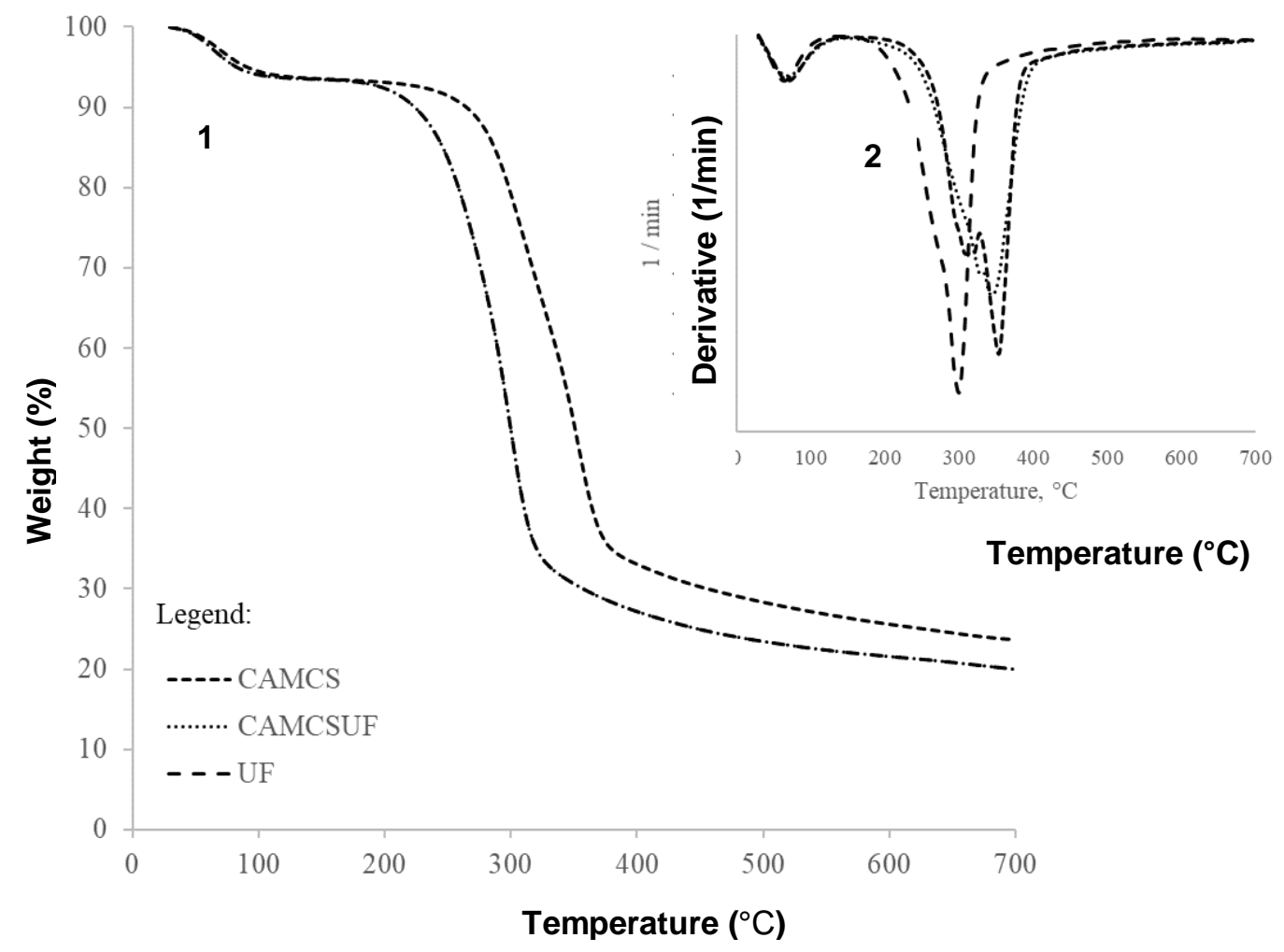

Fig. 3. Thermogravimetry curves, TG (1) and derivative thermogravimetry curves, DTG (2) for CAMCS wood composite, CAMCSUF wood composite and UF wood composite, respectively

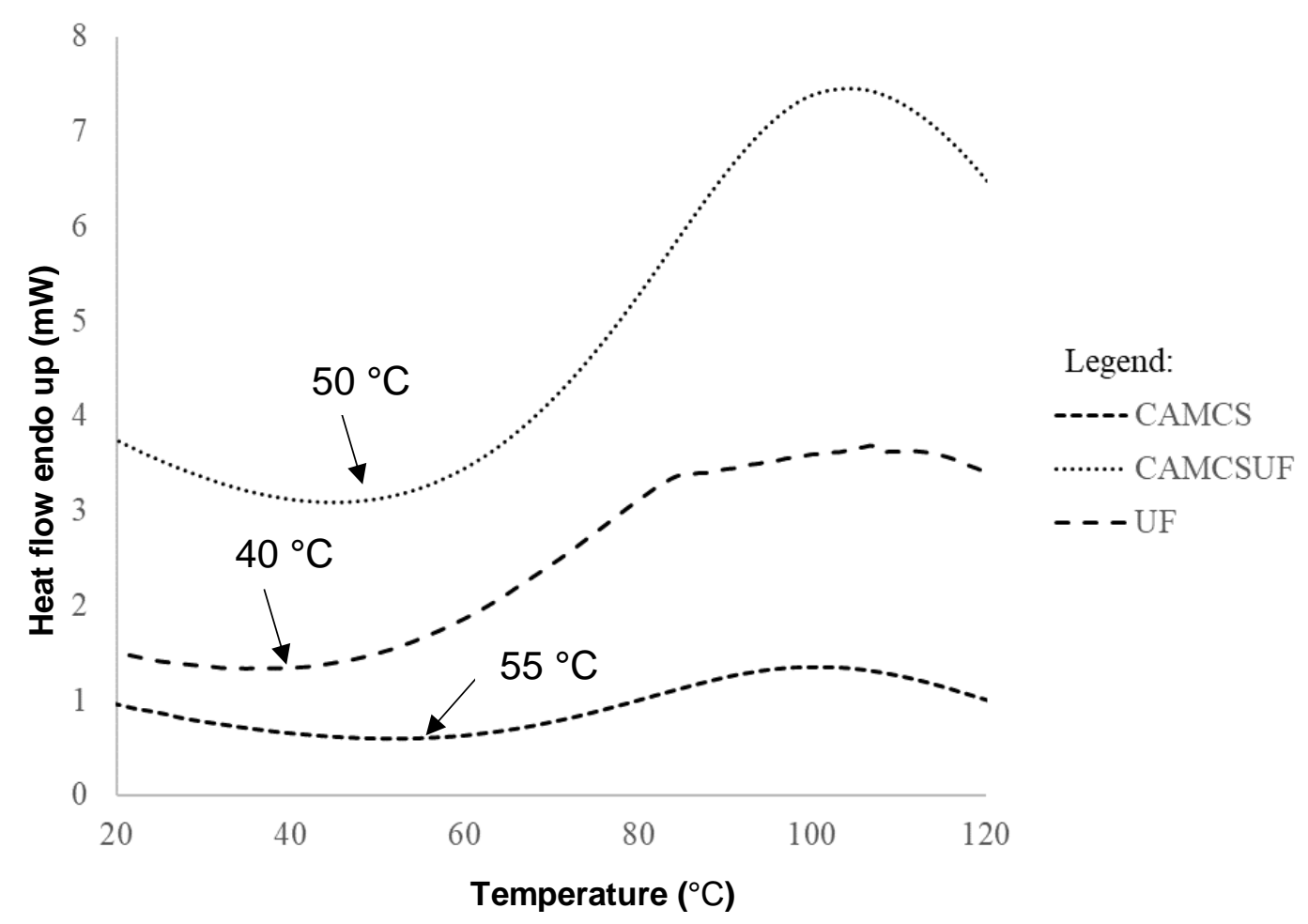

Fig. 4. DSC curves for CAMCS wood composite, CAMCSUF wood composite, and UF wood composite 
Changes of glass transition temperature of wood composite were observed via differential scanning calorimetry (DSC) analysis, which reflects the quality of chemical bonding (Cheremisinoff 1996). Figure 4 shows DSC curves for CAMCS wood composite (A), CAMCSUF wood composite (B), and UF wood composite (C). The first point of the curve instability was taken as the estimation of glass transition temperature (Bisanda et al. 2003), which were $50{ }^{\circ} \mathrm{C}, 40{ }^{\circ} \mathrm{C}$, and $55^{\circ} \mathrm{C}$ for wood composites made using CAMCS, CAMCSUF, and UF as binder. Melting points for wood composite made using CAMCS, CAMCSUF, and UF as binder were $88^{\circ} \mathrm{C}, 94^{\circ} \mathrm{C}$, and $95{ }^{\circ} \mathrm{C}$, respectively. The fact that more urea-formaldehyde in the binder mixture increased the melting point might have been due to better cross-linkages by urea-formaldehyde compared to modified starch.

\section{$X$-ray diffraction analysis}

The X-ray diffraction patterns of wood composites made using CAMCS, CAMCSUF, and UF as binder are shown in Fig. 5. Using urea formaldehyde as a binder reduced crystallinity index of wood composites. However, this is inconsistent, as CAMCSUF wood composite showed the highest crystallinity index. Therefore, X-ray diffraction analysis cannot solely be used as an indicator because the tested portion represented only a small part of wood composite. Calculations showed crystallinity index values of 19.2, 24.0, and 14.9\% for wood composites made using CAMCS, CAMCSUF, and UF as binder, respectively. Lower crystallinity index material contains more amorphous structure which binds better (Sulaiman et al. 2012). These indications were proven in mechanical testing which showed wood composite made using urea formaldeyde has higher mechanical strength.

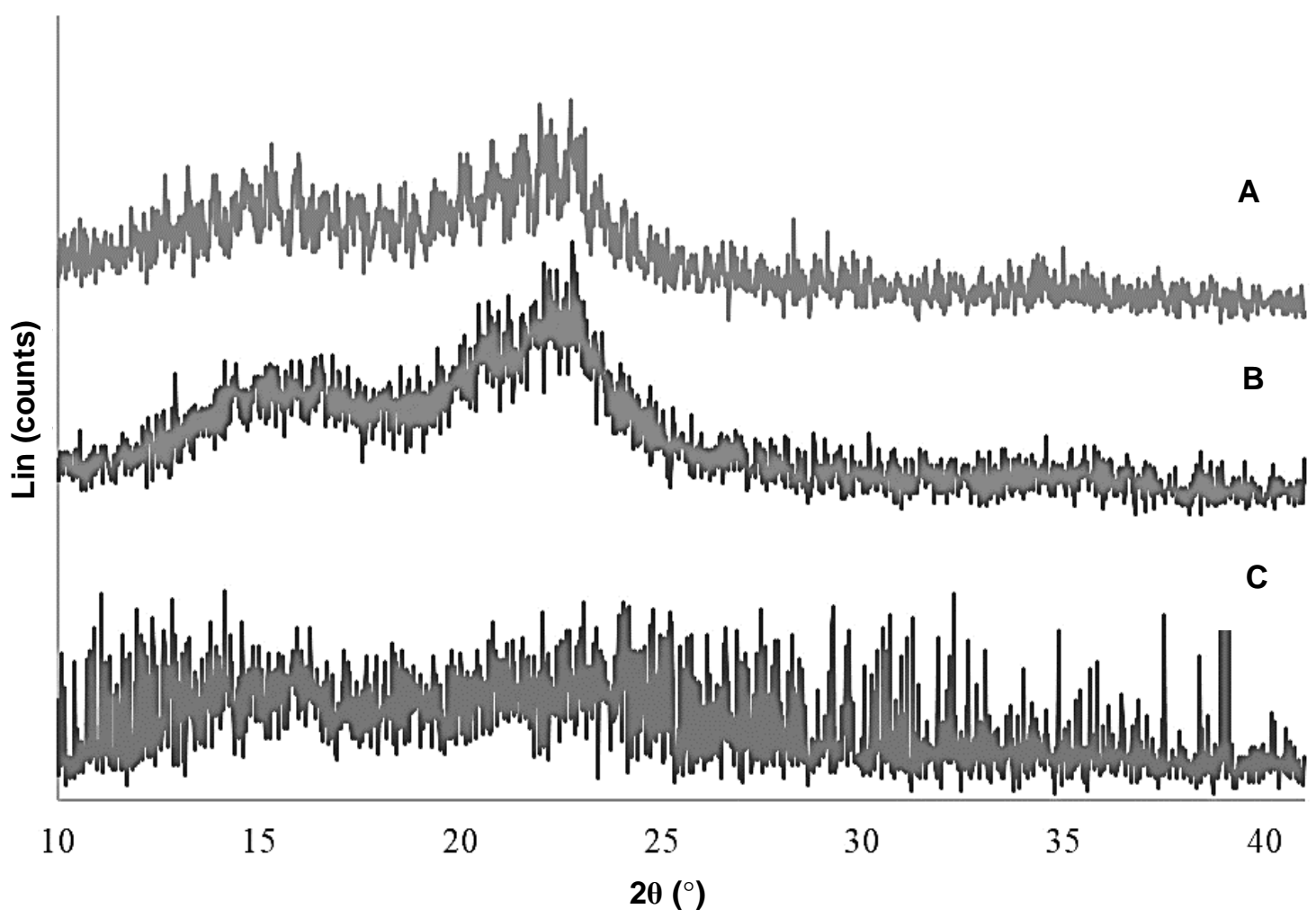

Fig. 5. X-ray diffraction pattern for CAMCS wood composite (A), CAMCSUF wood composite (B), and UF wood composite (C) 


\section{Physical Properties}

Table 1 shows density, moisture content, thickness swelling, and water absorption of manufactured CAMCS wood composite (A), CAMCSUF wood composite (B), and UF wood composite (C).

Table 1. Density, Moisture Content, Thickness Swelling, and Water Absorption of Manufactured CAMCS Wood Composite, CAMCSUF Wood Composite, and UF Wood Composite

\begin{tabular}{|c|c|c|c|c|c|c|c|}
\hline \multirow[t]{2}{*}{$\begin{array}{l}\text { Panel } \\
\text { Type }\end{array}$} & \multirow{2}{*}{$\begin{array}{l}\text { Target } \\
\text { Density } \\
\left(\mathrm{g} / \mathrm{cm}^{3}\right)\end{array}$} & \multirow{2}{*}{$\begin{array}{c}\text { Measured } \\
\text { Density } \\
\left(\mathrm{g} / \mathrm{cm}^{3}\right)\end{array}$} & \multirow{2}{*}{$\begin{array}{c}\text { Moisture } \\
\text { Content } \\
(\%)\end{array}$} & \multicolumn{2}{|c|}{$\begin{array}{c}\text { Thickness Swelling } \\
(\%)\end{array}$} & \multicolumn{2}{|c|}{ Water Absorption (\%) } \\
\hline & & & & $2 \mathrm{~h}$ & $24 \mathrm{~h}$ & $2 \mathrm{~h}$ & $24 \mathrm{~h}$ \\
\hline \multirow[t]{3}{*}{ CAMCS } & 0.60 & $\begin{array}{c}0.61 \\
(0.04) \mathrm{a}\end{array}$ & $\begin{array}{c}5.76 \\
(0.11) \mathrm{a}\end{array}$ & $\begin{array}{c}37.83 \\
(4.45) \mathrm{a}\end{array}$ & $\begin{array}{c}78.97 \\
(8.28) \mathrm{a}\end{array}$ & $\begin{array}{c}69.40 \\
(7.89) \mathrm{a}\end{array}$ & $\begin{array}{l}163.99 \\
(7.34) \mathrm{a}\end{array}$ \\
\hline & 0.70 & $\begin{array}{c}0.69 \\
(0.05) \mathrm{b}\end{array}$ & $\begin{array}{c}5.76 \\
(0.02) \mathrm{a}\end{array}$ & $\begin{array}{l}37.26 \\
(2.57) \mathrm{a}\end{array}$ & $\begin{array}{c}86.78 \\
(12.29) a\end{array}$ & $\begin{array}{c}62.65 \\
(4.49) \mathrm{b}\end{array}$ & $\begin{array}{c}151.43 \\
(12.78) a b\end{array}$ \\
\hline & 0.80 & $\begin{array}{c}0.78 \\
(0.06) \mathrm{c}\end{array}$ & $\begin{array}{c}5.61 \\
(0.18) \mathrm{b}\end{array}$ & $\begin{array}{l}35.85 \\
(9.82) \mathrm{a} \\
\end{array}$ & $\begin{array}{c}86.30 \\
(23.70) \mathrm{a} \\
\end{array}$ & $\begin{array}{l}54.51 \\
(7.81) \mathrm{c} \\
\end{array}$ & $\begin{array}{c}138.56 \\
(21.21) \mathrm{b} \\
\end{array}$ \\
\hline \multirow[t]{3}{*}{ CAMCSUF } & 0.60 & $\begin{array}{c}0.58 \\
(0.03) \mathrm{a}\end{array}$ & $\begin{array}{c}4.12 \\
(0.08) a\end{array}$ & $\begin{array}{c}32.01 \\
(5.56) \mathrm{a}\end{array}$ & $\begin{array}{c}76.40 \\
(7.99) a\end{array}$ & $\begin{array}{c}62.02 \\
(16.84) \mathrm{a}\end{array}$ & $\begin{array}{c}152.16 \\
(15.49) \mathrm{a}\end{array}$ \\
\hline & 0.70 & $\begin{array}{c}0.67 \\
(0.06) \mathrm{b}\end{array}$ & $\begin{array}{c}4.54 \\
(0.08) \mathrm{b}\end{array}$ & $\begin{array}{c}30.92 \\
(11.66) \mathrm{a}\end{array}$ & $\begin{array}{c}67.25 \\
(12.48) \mathrm{b}\end{array}$ & $\begin{array}{c}56.35 \\
(20.03) \mathrm{a}\end{array}$ & $\begin{array}{c}143.60 \\
(18.98) \mathrm{b}\end{array}$ \\
\hline & 0.80 & $\begin{array}{c}0.78 \\
(0.02) \mathrm{c}\end{array}$ & $\begin{array}{c}3.72 \\
(0.38) c\end{array}$ & $\begin{array}{c}30.41 \\
(9.31) a\end{array}$ & $\begin{array}{c}69.24 \\
(11.49) \mathrm{b}\end{array}$ & $\begin{array}{c}52.09 \\
(9.21) \mathrm{a}\end{array}$ & $\begin{array}{c}127.69 \\
(10.48) b\end{array}$ \\
\hline \multirow[t]{3}{*}{ UF } & 0.60 & $\begin{array}{c}0.56 \\
(0.03) \mathrm{a}\end{array}$ & $\begin{array}{c}4.59 \\
(0.11) \mathrm{a}\end{array}$ & $\begin{array}{c}16.54 \\
(3.64) \mathrm{a}\end{array}$ & $\begin{array}{c}38.59 \\
(6.99) \mathrm{a}\end{array}$ & $\begin{array}{c}48.88 \\
(9.37) \mathrm{a}\end{array}$ & $\begin{array}{c}111.58 \\
(21.69) \mathrm{a}\end{array}$ \\
\hline & 0.70 & $\begin{array}{c}0.68 \\
(0.04) \mathrm{b}\end{array}$ & $\begin{array}{c}4.50 \\
(0.01) \mathrm{a}\end{array}$ & $\begin{array}{c}19.29 \\
(2.61) b\end{array}$ & $\begin{array}{c}46.72 \\
(5.81) \mathrm{b}\end{array}$ & $\begin{array}{c}44.94 \\
(4.40) \mathrm{ab}\end{array}$ & $\begin{array}{c}97.46 \\
(6.36) \mathrm{a}\end{array}$ \\
\hline & 0.80 & $\begin{array}{c}0.78 \\
(0.13) \mathrm{c}\end{array}$ & $\begin{array}{c}4.07 \\
(0.10) \mathrm{b}\end{array}$ & $\begin{array}{c}18.84 \\
(2.59) \mathrm{ab}\end{array}$ & $\begin{array}{c}48.52 \\
(6.43) \mathrm{b}\end{array}$ & $\begin{array}{c}41.67 \\
(11.70) \mathrm{b}\end{array}$ & $\begin{array}{c}100.33 \\
(23.52) \mathrm{a}\end{array}$ \\
\hline
\end{tabular}

*Values in parentheses represents standard deviation.

${ }^{* *}$ different letters in a same column, within same adhesive type, show significant difference at a value of 0.05

\section{Measured density and dimensional stability after water immersion}

Measurement of density of wood composites was carried out to evaluate the accuracy of the wood composite making process. Accuracy of density level is important because it affects overall properties of produced wood composites. The results showed that the wood composites had been made with strong accuracy toward their targeted density levels. Measured density for the targeted density level of $0.60 \mathrm{~g} / \mathrm{cm}^{3}$ ranged from 0.56 $\mathrm{g} / \mathrm{cm}^{3}$ to $0.61 \mathrm{~g} / \mathrm{cm}^{3}$. Meanwhile, for wood composites made for target densities of 0.70 $\mathrm{g} / \mathrm{cm}^{3}$ and $0.80 \mathrm{~g} / \mathrm{cm}^{3}$, measured densities showed density ranges of $0.67 \mathrm{~g} / \mathrm{cm}^{3}$ to 0.69 $\mathrm{g} / \mathrm{cm}^{3}$ and consistently at $0.78 \mathrm{~g} / \mathrm{cm}^{3}$, respectively. Significant level evaluation using the Tukey test was performed for every type of wood composite showed that wood composites were remarkably different from each other when compared between different densities. These results indicated that wood composites were well-manufactured according to their expected specifications. Moisture content was maintained between $3.72 \%$ to $5.76 \%$ with only a small number of samples noticeably different from each other when compared to same density levels.

Thickness swelling and water absorption evaluation are essential tests to evaluate dimensional stability and suitability of wood panels to be used in areas that involve direct 
contact of wood composite with moisture. Changes in dimensions of wood composite that result from changes in moisture content should be determined to avoid possible problems related to linear expansion and thickness swelling, which could lead to load-carrying capacity and stiffness problems (McNatt 1974). Table 1 also shows thickness swelling of manufactured wood composites after $2 \mathrm{~h}$ and $24 \mathrm{~h}$ of immersion in water. Most of the time, thickness swelling was increased as the density level of wood composites increased. Due to the release of residual compressive stresses imparted to the board during pressing of the mat in the hot press, thickness swelling occurred. This phenomenon is also called "spring back," which refers to non-recoverable thickness swelling that occurs when the finished wood composite is exposed to an elevated humidity or liquid water (Kelly 1977). Surface of samples also played an important role in thickness swelling of wood composites. A porous surface allowed more water to penetrate wood composites. Therefore, some lower density wood composites had more swelling in thickness than higher density wood composites.

Wood composites with cross-linked starch showed greater resistance towards water uptake because of reduction of hydroxyl groups of native starch after a condensation reaction as well as formation of three-dimensional networking during curing processes (Kaith et al. 2010). This was demonstrated by FT-IR, where $\mathrm{OH}$ peaks for wood composite made using modified starch as binder at around $2900 \mathrm{~cm}^{-1}$ showed lower intensity compared to wood composites made using native starch as binder. Taking wood composite at a density level of $0.80 \mathrm{~g} / \mathrm{cm}^{3}$ as an example, using modified starch reduced $2 \mathrm{~h}$ thickness swelling for $11.4 \%$ for wood composites made using CAMCS, and it was further improved by addition of $2 \%$ urea-formaldehyde resin, with decreases of thickness swelling determined as $16.9 \%$ for wood composite made using CAMCSUF.

It was also observed that longer soaking time increased thickness swelling of wood composites. This was attributed to the fact that longer soaking time providing more time for moisture to break hydrogen linkages in samples, allowing more water to be absorbed and further to break more hydrogen linkages, which thus increased thickness swelling. Table 1 also includes statistical analysis of thickness swelling and water absorption of wood composites after $2 \mathrm{~h}$ and $24 \mathrm{~h}$ immersion in water, compared between different densities and binder types. Statistical analysis of $2 \mathrm{~h}$ thickness swelling showed that most sample comparisons were not remarkably different for wood composites made at a density level of $0.60 \mathrm{~g} / \mathrm{cm}^{3}, 0.70 \mathrm{~g} / \mathrm{cm}^{3}$, and $0.80 \mathrm{~g} / \mathrm{cm}^{3}$, respectively. Longer soaking time had caused all samples to swell to maximum where moisture broke many linkages until difference in binder type showed a lesser effect in thickness swelling properties. Results of thickness swelling for all manufactured wood composites did not comply with the minimum requirements in JIS A 5908 (2003), which limits up to $12 \%$ of thickness swelling after immersion in water. Thus, improvement, such as incorporation of water repellent materials, is necessary for future usage.

\section{Effect of relative humidity on dimensional stability}

Thickness swelling of manufactured wood composites at 35\%, 55\%, 75\%, and 95\% relative humidity are shown in Table 2 . Lower relative humidity of $35 \%$ resulted in a decrease in sample thickness. Thickness swelling of wood composites in different relative humidity depended on open surface of samples that allowed for penetration of moisture. Thickness swelling at $55 \%$ of relative humidity showed that $30 \%$ of samples were still experiencing shrinkages while others began to swell. Reaching $75 \%$ of relative humidity, all samples expanded between $0.68 \%$ and $3.21 \%$. Higher relative humidity at $95 \%$

Amini et al. (2020). "Environmentally friendly binder," BioResources 15(2), 4234-4248. 
increased thickness swelling between $6.7 \%$ and $18.4 \%$. Even though the minimum requirement for thickness swelling in different relative humidity for wood composites is not stated in JIS A 5908 (JIS A 5908 2003), these results could be used as indications on how wood composites react to different humidity surroundings. Water absorption was additionally related with relative humidity. As additionally tabulated in Table 2, wood composite samples expelled water at 35\% relative humidity, where lower surrounding humidity forced samples to balance their moisture content by releasing moisture. As a result, all wood composite samples showed negative values of water absorption where initial sample weight was higher than final weight.

Table 2. Thickness Swelling for CAMCS Wood Composite, CAMCSUF Wood Composite, and UF Wood Composite at Different Relative Humidity

\begin{tabular}{|c|c|c|c|c|c|c|c|c|c|}
\hline \multirow[t]{2}{*}{$\begin{array}{l}\text { Panel } \\
\text { Type }\end{array}$} & \multirow{2}{*}{$\begin{array}{c}\text { Target } \\
\text { Dens- } \\
\text { ity } \\
\left(\mathrm{g} / \mathrm{cm}^{3}\right) \\
\end{array}$} & \multicolumn{4}{|c|}{$\begin{array}{c}\text { Thickness Swelling at Relative } \\
\text { Humidity }\end{array}$} & \multicolumn{4}{|c|}{ Water Absorption at Relative Humidity } \\
\hline & & $35 \%$ & $55 \%$ & $75 \%$ & $95 \%$ & $35 \%$ & $55 \%$ & $75 \%$ & $95 \%$ \\
\hline \multirow{3}{*}{$\sum_{0}^{\infty}$} & 0.60 & $\begin{array}{l}-2.49 \\
(0.12) \mathrm{a}\end{array}$ & $\begin{array}{c}0.32 \\
(0.02) \mathrm{a}\end{array}$ & $\begin{array}{c}3.21 \\
(0.07) \mathrm{a}\end{array}$ & $\begin{array}{l}18.35 \\
(0.40) \mathrm{a}\end{array}$ & $\begin{array}{l}-3.51 \\
(0.53) \mathrm{a}\end{array}$ & $\begin{array}{l}-0.18 \\
(0.03) a\end{array}$ & $\begin{array}{c}2.90 \\
(0.19) \mathrm{a}\end{array}$ & $\begin{array}{c}8.61 \\
(0.49) \mathrm{ab}\end{array}$ \\
\hline & 0.70 & $\begin{array}{l}-2.21 \\
(0.11) \mathrm{b}\end{array}$ & $\begin{array}{c}0.54 \\
(0.01) \mathrm{b}\end{array}$ & $\begin{array}{c}3.21 \\
(0.07) \mathrm{a}\end{array}$ & $\begin{array}{c}9.77 \\
(0.61) \mathrm{b}\end{array}$ & $\begin{array}{c}-3.20 \\
(0.37) \mathrm{ab} \\
\end{array}$ & $\begin{array}{c}-0.38 \\
(0.02) \mathrm{b}\end{array}$ & $\begin{array}{c}2.88 \\
(0.17) \mathrm{a}\end{array}$ & $\begin{array}{c}9.78 \\
(1.66) \mathrm{a}\end{array}$ \\
\hline & 0.80 & $\begin{array}{l}-2.42 \\
(0.05) \mathrm{a}\end{array}$ & $\begin{array}{c}-0.64 \\
(0.04) c\end{array}$ & $\begin{array}{c}1.13 \\
(0.05) \mathrm{b}\end{array}$ & $\begin{array}{l}14.43 \\
(0.65) \mathrm{c}\end{array}$ & $\begin{array}{l}-2.94 \\
(0.13) \mathrm{b}\end{array}$ & $\begin{array}{c}-0.31 \\
(0.04) c\end{array}$ & $\begin{array}{c}2.47 \\
(0.26) \mathrm{b}\end{array}$ & $\begin{array}{c}8.23 \\
(0.83) \mathrm{b}\end{array}$ \\
\hline \multirow{3}{*}{ 岇 } & 0.60 & $\begin{array}{l}-1.52 \\
(0.03) \mathrm{a}\end{array}$ & $\begin{array}{c}1.32 \\
(0.06) \mathrm{a}\end{array}$ & $\begin{array}{c}2.45 \\
(0.14) \mathrm{a}\end{array}$ & $\begin{array}{c}6.71 \\
(0.30) \mathrm{a}\end{array}$ & $\begin{array}{l}-3.10 \\
(0.17) \mathrm{a}\end{array}$ & $\begin{array}{l}-0.06 \\
(0.01) \mathrm{a}\end{array}$ & $\begin{array}{c}3.13 \\
(0.50) \mathrm{a}\end{array}$ & $\begin{array}{c}8.96 \\
(0.93) \mathrm{a}\end{array}$ \\
\hline & 0.70 & $\begin{array}{l}-1.18 \\
(0.03) b\end{array}$ & $\begin{array}{c}0.76 \\
(0.02) \mathrm{b}\end{array}$ & $\begin{array}{c}2.72 \\
(0.13) \mathrm{b}\end{array}$ & $\begin{array}{c}9.91 \\
(0.57) \mathrm{b}\end{array}$ & $\begin{array}{l}-2.78 \\
(0.14) \mathrm{b}\end{array}$ & $\begin{array}{c}0.08 \\
(0.01) \mathrm{b}\end{array}$ & $\begin{array}{c}2.87 \\
(0.31) \mathrm{a}\end{array}$ & $\begin{array}{c}8.36 \\
(1.19) \mathrm{a}\end{array}$ \\
\hline & 0.80 & $\begin{array}{l}-1.25 \\
(0.05) c\end{array}$ & $\begin{array}{c}0.46 \\
(0.02) \mathrm{c}\end{array}$ & $\begin{array}{c}2.11 \\
(0.09) c\end{array}$ & $\begin{array}{l}13.52 \\
(0.26) c\end{array}$ & $\begin{array}{c}-3.04 \\
(0.25) a\end{array}$ & $\begin{array}{c}-0.27 \\
(0.02) c\end{array}$ & $\begin{array}{c}2.50 \\
(0.21) \mathrm{b}\end{array}$ & $\begin{array}{c}8.32 \\
(0.32) a\end{array}$ \\
\hline \multirow{3}{*}{ 屿 } & 0.60 & $\begin{array}{c}-1.11 \\
(0.05) a\end{array}$ & $\begin{array}{c}1.60 \\
(0.09) \mathrm{a}\end{array}$ & $\begin{array}{c}1.06 \\
(0.06) \mathrm{a}\end{array}$ & $\begin{array}{c}9.70 \\
(0.56) \mathrm{a}\end{array}$ & $\begin{array}{c}-2.90 \\
(0.37) \mathrm{a}\end{array}$ & $\begin{array}{c}-0.07 \\
(0.01) a\end{array}$ & $\begin{array}{c}2.71 \\
(0.43) a\end{array}$ & $\begin{array}{c}6.82 \\
(1.07) \mathrm{a}\end{array}$ \\
\hline & 0.70 & $\begin{array}{c}-2.27 \\
(0.09) b\end{array}$ & $\begin{array}{c}1.22 \\
(0.05) b\end{array}$ & $\begin{array}{c}2.03 \\
(0.08) b\end{array}$ & $\begin{array}{c}10.75 \\
(0.21) b\end{array}$ & $\begin{array}{c}-2.78 \\
(0.27) \mathrm{a}\end{array}$ & $\begin{array}{c}-0.09 \\
(0.01) a\end{array}$ & $\begin{array}{c}2.64 \\
(0.28) a\end{array}$ & $\begin{array}{c}8.25 \\
(0.38) b\end{array}$ \\
\hline & 0.80 & $\begin{array}{c}-2.80 \\
(0.11) c\end{array}$ & $\begin{array}{c}1.71 \\
(0.06) \mathrm{c}\end{array}$ & $\begin{array}{c}1.94 \\
(0.07) \mathrm{c} \\
\end{array}$ & $\begin{array}{c}11.54 \\
(0.54) \mathrm{C}\end{array}$ & $\begin{array}{c}-2.83 \\
(0.26) \mathrm{a}\end{array}$ & $\begin{array}{c}-0.23 \\
(0.02) \mathrm{b}\end{array}$ & $\begin{array}{c}2.49 \\
(0.24) \mathrm{a}\end{array}$ & $\begin{array}{c}8.75 \\
(1.07) \mathrm{b}\end{array}$ \\
\hline
\end{tabular}

*Values in parentheses represents standard deviation

${ }^{* *}$ different letter in a same column, within same adhesive type, shows significant difference at a value of 0.05

\section{Mechanical Properties}

At all density levels, using modified starch as binder increased amounts of crosslinking between wood particles and additionally between wood particles and binder, which gave sufficiently high bending strength as required in Japanese Industrial Standard, JIS A 5908 (2003). Table 3 shows that bending strength and stiffness increased steadily with additional urea-formaldehyde in the adhesive mixture. The MOR at $0.80 \mathrm{~g} / \mathrm{cm}^{3}$ density level was increased from 16.8 to 17.9 and $25.5 \mathrm{~N} / \mathrm{mm}^{2}$ for CAMCS, CAMCSUF and UF wood composites, respectively. The MOE also showed increment from 4019 to 5191 and $5039 \mathrm{~N} / \mathrm{mm}^{2}$ for CAMCS, CAMCSUF, and UF wood composites, respectively. The density level also affects the strength of the wood composite. Each adhesive type shows increment of MOR and MOE as the density was increased from $0.60 \mathrm{~g} / \mathrm{cm}^{3}$ to 0.80 $\mathrm{g} / \mathrm{cm}^{3}$. Higher density wood composites contained a higher amount of fiber in the same 
volume, which resulted in denser structure and higher strength. The same fashion was shown for internal bonding strength where urea formaldehyde improved the mechanical property of the composite. At $0.80 \mathrm{~g} / \mathrm{cm}^{3}$, the internal bonding strength was increased from 0.88 to 0.95 and $1.14 \mathrm{~N} / \mathrm{mm}^{2}$ for CAMCS, CAMCSUF, and UF wood composites, respectively. All wood composite samples, regardless of their density, passed the requirement for internal bonding strength of wood composite by JIS A 5908 (2003), which set $0.15 \mathrm{~N} / \mathrm{mm}^{2}$ as minimum strength value. Comparisons with other types of wood composites are tabulated in Table 4.

Table 3. Bending Test and Internal Bonding Strength of CAMCS Wood Composite, CAMCSUF Wood Composite, and UF Wood Composite

\begin{tabular}{|c|c|c|c|c|}
\hline \multirow[t]{2}{*}{ Panel Type } & \multirow{2}{*}{$\begin{array}{l}\text { Target } \\
\text { Density } \\
\left(\mathrm{g} / \mathrm{cm}^{3}\right)\end{array}$} & \multicolumn{2}{|c|}{ Bending Test $\left(\mathrm{N} / \mathrm{mm}^{2}\right)$} & \multirow{2}{*}{$\begin{array}{l}\text { Internal } \\
\text { Bonding } \\
\left(\mathrm{N} / \mathrm{mm}^{2}\right)\end{array}$} \\
\hline & & $\begin{array}{c}\text { Modulus of Rupture, } \\
\text { MOR }\end{array}$ & $\begin{array}{c}\text { Modulus of Elasticity, } \\
\text { MOE }\end{array}$ & \\
\hline \multirow[t]{3}{*}{ CAMCS } & 0.60 & $8.56(2.65) a$ & $1625.28(514.25) \mathrm{a}$ & $0.65(0.13) a$ \\
\hline & 0.70 & $14.11(2.66) \mathrm{b}$ & $3084.48(401.46) b$ & $0.71(0.13) a$ \\
\hline & 0.80 & $16.83(3.63) b$ & $4018.58(637.06) c$ & $0.88(0.13) b$ \\
\hline \multirow[t]{3}{*}{ CAMCSUF } & 0.60 & $9.42(1.94) \mathrm{a}$ & 2380.37 (1083.68)a & $0.70(0.09) \mathrm{a}$ \\
\hline & 0.70 & $15.57(3.73) b$ & 3399.60 (1117.47)a & $0.87(0.24) a b$ \\
\hline & 0.80 & $17.87(5.04) b$ & $5190.70(873.23) \mathrm{b}$ & $0.95(0.14) a$ \\
\hline \multirow[t]{3}{*}{ UF } & 0.60 & $14.83(5.25) \mathrm{a}$ & 2599.94 (683.36)a & $0.94(0.31) a$ \\
\hline & 0.70 & 19.66 (3.41)ab & $3543.45(576.45) b$ & $0.98(0.26) a$ \\
\hline & 0.80 & $25.54(5.67) \mathrm{b}$ & $5039.47(739.94) c$ & $1.14(0.16) \mathrm{a}$ \\
\hline
\end{tabular}

${ }^{*}$ Values in parentheses represents standard deviation

**different letter in a same column, within same adhesive type, shows significant difference at a value of 0.05

Table 4. Strength Comparisons of Different Types of Wood Composites with this Work

\begin{tabular}{|c|c|c|c|c|c|}
\hline \multirow[t]{2}{*}{ Panel Type } & \multirow{2}{*}{$\begin{array}{l}\text { Target } \\
\text { Density } \\
\left(\mathrm{g} / \mathrm{cm}^{3}\right)\end{array}$} & \multicolumn{2}{|c|}{ Bending Test $\left(\mathrm{N} / \mathrm{mm}^{2}\right)$} & \multirow{2}{*}{$\begin{array}{l}\text { Internal } \\
\text { Bonding } \\
\left(\mathrm{N} / \mathrm{mm}^{2}\right)\end{array}$} & \multirow[t]{2}{*}{ Reference } \\
\hline & & $\begin{array}{l}\text { Modulus of } \\
\text { Rupture, } \\
\text { MOR }\end{array}$ & $\begin{array}{l}\text { Modulus of } \\
\text { Elasticity, } \\
\text { MOE }\end{array}$ & & \\
\hline CAMCS & 0.80 & 16.8 & 4019 & 0.88 & This work \\
\hline CAMCSUF & 0.80 & 17.9 & 5191 & 0.95 & This work \\
\hline $\begin{array}{l}\text { Citric acid-bonded wood } \\
\text { composite from bamboo }\end{array}$ & 0.90 & 14.0 & 4000 & 0.40 & $\begin{array}{l}\text { (Widyorini et } \\
\text { al. 2016) }\end{array}$ \\
\hline $\begin{array}{l}\text { Sweet sorghum } \\
\text { bagasse and citric acid }\end{array}$ & 0.80 & 23.0 & 3200 & 0.90 & $\begin{array}{l}\text { (Kusumah et } \\
\text { al. 2016) }\end{array}$ \\
\hline Phenolated lignins & 0.70 & - & - & 0.75 & $\begin{array}{l}\text { (Podschun } \\
\text { et al. 2016) }\end{array}$ \\
\hline Soy and tannin mixture & 0.70 & 7.5 & 2295 & 0.28 & $\begin{array}{l}\text { (Ghahri and } \\
\text { Pizzi 2018) }\end{array}$ \\
\hline $\begin{array}{l}\text { Non-isocyanate } \\
\text { polyurethane adhesive } \\
\text { from sucrose }\end{array}$ & 0.71 & 19.1 & 3186 & 1.02 & $\begin{array}{l}\text { (Xi et al. } \\
2019)\end{array}$ \\
\hline $\begin{array}{l}\text { Epichlorohydrin- } \\
\text { modified rice starch as } \\
\text { binder }\end{array}$ & 0.80 & 23.0 & 3692 & 0.64 & $\begin{array}{l}\text { (Sulaiman et } \\
\text { al. 2016) }\end{array}$ \\
\hline $\begin{array}{c}\text { Glutaraldehyde- } \\
\text { modified corn starch } \\
\text { with urea-formaldehyde }\end{array}$ & 0.80 & 22.9 & 4983 & 1.13 & $\begin{array}{l}\text { (Amini et al. } \\
\text { 2015) }\end{array}$ \\
\hline
\end{tabular}




\section{Fungal Resistance}

Schizophyllum commune is a white rot basidiomycetes that can degrade lignin and polysaccharides (Horisawa et al. 2015). For CAMCS wood composite, average degradation by Schizophyllum commune was $17.8 \%$, followed by CAMCSUF at $17.2 \%$, and least affected was UF-bonded wood composite at $8.5 \%$. Another white rot fungus, Pycnoporus sanguineus, attacked more aggressively with 19.8\%, 21.9\%, and $12.8 \%$ average degradation for CAMCS, CAMCSUF, and UF-bonded wood composites, respectively. Meanwhile, Formitopsis palustris fungi, which was reported to cause wood brown rot, also caused enzymatic breakdown of cellulose (Zhao et al. 2018). Average sample degradation was $13.0 \%, 25.4 \%$, and $7.6 \%$ for CAMCS, CAMCSUF, and UF, respectively. Lastly is Trametes versicolor, which is also a white rot fungi. Degradation after exposure to Trametes versicolor was $15.6 \%, 14.6 \%$, and $11.7 \%$ for CAMCS, CAMCSUF, and UF, respectively, where less degradation was observed as ureaformaldehyde was added to mixture.

Table 5. Fungal Degradation Test of Manufactured Wood Composites

\begin{tabular}{|c|c|c|c|c|c|}
\hline Panel Type & Target & \multicolumn{5}{|c|}{ Fungal Exposure Test, Decay (\%) } \\
\cline { 2 - 6 } & $\begin{array}{c}\text { Density } \\
\left(\mathrm{g} / \mathrm{cm}^{3}\right.\end{array}$ & $\begin{array}{c}\text { Schizophyllum } \\
\text { commune }\end{array}$ & $\begin{array}{c}\text { Pycnoporus } \\
\text { sanguineus }\end{array}$ & $\begin{array}{c}\text { Formitopsis } \\
\text { palustris }\end{array}$ & $\begin{array}{c}\text { Trametes } \\
\text { versicolor }\end{array}$ \\
\hline \multirow{3}{*}{ CAMCS } & 0.60 & $20.60(1.33) \mathrm{a}$ & $19.16(1.89) \mathrm{a}$ & $13.27(1.65) \mathrm{a}$ & $17.05(0.90) \mathrm{a}$ \\
\cline { 2 - 6 } & 0.70 & $13.82(0.39) \mathrm{b}$ & $19.58(2.67) \mathrm{a}$ & $9.99(0.27) \mathrm{b}$ & $17.13(0.33) \mathrm{a}$ \\
\cline { 2 - 6 } & 0.80 & $18.90(0.84) \mathrm{c}$ & $20.79(0.64) \mathrm{a}$ & $15.90(1.26) \mathrm{c}$ & $12.53(0.55) \mathrm{b}$ \\
\hline CAMCSUF & 0.60 & $18.12(0.11) \mathrm{a}$ & $17.28(1.86) \mathrm{a}$ & $19.32(0.39) \mathrm{a}$ & $12.98(1.34) \mathrm{a}$ \\
\cline { 2 - 6 } & 0.70 & $17.94(0.76) \mathrm{a}$ & $31.96(1.77) \mathrm{b}$ & $20.20(1.66) \mathrm{a}$ & $15.03(0.96) \mathrm{b}$ \\
\cline { 2 - 6 } & 0.80 & $15.45(3.07) \mathrm{b}$ & $16.36(2.05) \mathrm{a}$ & $36.84(1.00) \mathrm{b}$ & $15.88(1.27) \mathrm{b}$ \\
\hline \multirow{3}{*}{ UF } & 0.60 & $9.86(0.34) \mathrm{a}$ & $16.57(1.85) \mathrm{a}$ & $12.57(0.48) \mathrm{a}$ & $8.34(1.01) \mathrm{a}$ \\
\cline { 2 - 7 } & 0.70 & $6.72(1.60) \mathrm{b}$ & $8.63(1.00) \mathrm{b}$ & $6.21(1.34) \mathrm{b}$ & $13.84(1.45) \mathrm{b}$ \\
\cline { 2 - 7 } & 0.80 & $8.98(1.46) \mathrm{a}$ & $13.19(1.24) \mathrm{c}$ & $3.88(0.66) \mathrm{c}$ & $12.94(1.39) \mathrm{b}$ \\
\hline
\end{tabular}

*Values in parentheses represents standard deviation.

**Different letter in a same column, within same adhesive type, shows significant difference at a value of 0.05 .

\section{CONCLUSIONS}

1. FT-IR analysis showed an ester group at $1736.8 \mathrm{~cm}^{-1}$, which is characteristic for starch modified with citric acid.

2. All test specimens passed mechanical strength requirements by JIS A 5908 (2003).

3. Bending test on CAMCS wood composite showed $16.8 \mathrm{~N} / \mathrm{mm}^{2}$ and $4020 \mathrm{~N} / \mathrm{mm}^{2}$ for modulus of rupture and modulus of elasticity, respectively.

4. Addition of $2 \%$ urea-formaldehyde to the citric acid-modified corn starch increased the modulus of rupture and modulus of elasticity to $17.9 \mathrm{~N} / \mathrm{mm}^{2}$ and $5190 \mathrm{~N} / \mathrm{mm}^{2}$, respectively.

5. The internal bonding increased from $0.88 \mathrm{~N} / \mathrm{mm}^{2}$ to $0.95 \mathrm{~N} / \mathrm{mm}^{2}$ with urea formaldeyde addition.

6. Fungal degradation of citric acid-modified starch ranged from $10.0 \%$ to $20.8 \%$. 
7. Depending on the required specification for the final usage of the wood composite, it can be concluded that citric acid modified starch is a possible alternative as the adhesive, with or without additional urea formaldehyde resin.

\section{ACKNOWLEDGMENTS}

The authors are grateful to the Ministry of Higher Education Malaysia for Research Acculturation Grant Scheme (R/RAGS/A08.00/01046A/002/2015/000302) for Mohd Hazim Mohamad Amini and Universiti Sains Malaysia for the Research University (Grant No. 1001/PTEKIND/815066) to Rokiah Hashim. The authors also acknowledge Heveaboard (Malaysia) Sdn Bhd for providing raw materials for composite making.

\section{REFERENCES CITED}

Amini, M. H. M., Hashim, R., Hiziroglu, S., Sulaiman, N. S., and Sulaiman, O. (2013). "Properties of particleboard made from rubberwood using modified starch as binder," Compos. Part B- Eng. 50, 259-264. DOI: 10.1016/j.compositesb.2013.02.020

Amini, M. H. M., Hashim, R., Hiziroglu, S., and Sulaiman, O. (2012). "Citric acid modified oil palm starch as an environmental friendly adhesive for particleboard making - Preliminary results on mechanical properties," in: International Conference on Environmental Research and Technology (ICERT 2012), Universiti Sains Malaysia, Penang, Malaysia, pp. 129-132.

Amini, M. H. M., Hashim, R., Sulaiman, N. S., Hiziroglu, S., Sulaiman, O., Mohamed, M., and Rasat, M. S. M. (2015). "Glutardialdehyde modified corn starch - Ureaformaldehyde resin as a binder for particleboard making," Appl. Mech. Mater. 754755, 89-93. DOI: 10.4028/www.scientific.net/AMM.754-755.89

Amini, M. H. M., Hashim, R., Sulaiman, N. S., Sulaiman, O., Sulaiman, S. F., Abood, F., Kawamura, F., Wahab, R., Mohamed, M., and Rasat, M. S. M. (2015). "Antibacterial activity of different biomass components of Cerbera odollam and their potential to be used as new preservative for wood based products," Appl. Mech. Mater. 754-755, 1040-1044.

Bisanda, E. T. N., Ogola, W. O., and Tesha, J. V. (2003). "Characterisation of tannin resin blends for particle board applications," Cem. Concr. Compos. 25(6), 593-598. DOI: 10.1016/S0958-9465(02)00072-0

Cheremisinoff, N. P. (1996). Polymer Characterization - Laboratory Techniques and Analysis, Noyes Publications, Park Ridge, NJ, USA.

Gašparovič, L., Koreňová, Z., and Jelemenský, L. (2010). "Kinetic study of wood chips decomposition by TGA," Chem. Pap. 64(2), 174-181. DOI: 10.2478/s11696-0090109-4

Ghahri, S., and Pizzi, A. (2018). "Improving soy-based adhesives for wood particleboard by tannins addition," Wood Sci. Technol 52(1), 261-279. DOI: 10.1007/s00226-0170957-y

Hermawan, D., Hata, T., Kawai, S., Nagadomi, W., and Kuroki, Y. (2002). "Manufacturing oil palm fronds cement-bonded board cured by gaseous or supercritical carbon dioxide," J. Wood Sci. 48(1), 20-24. DOI: 10.1007/BF00766233 
Horisawa, S., Ando, H., Ariga, O., and Sakuma, Y. (2015). "Direct ethanol production from cellulosic materials by consolidated biological processing using the wood rot fungus Schizophyllum commune," Bioresource Technol. 197, 37-41. DOI: 10.1016/j.biortech.2015.08.031

JIS A 5908 (2003). "Particleboards," Japanese Standards Association, Tokyo, Japan.

Kaith, B. S., Jindal, R., Jana, A. K., and Maiti, M. (2010). "Development of corn starch based green composites reinforced with Saccharum spontaneum L. fiber and graft copolymers - Evaluation of thermal, physico-chemical and mechanical properties," Bioresource Technol. 101(17), 6843-6851. DOI: 10.1016/j.biortech.2010.03.113

Kelly, M. W. (1977). Critical Literature Review of Relationships Between Processing Parameters and Physical Properties of Particleboard (General Technical Report FPL-10), U.S. Department of Agriculture Forest Products Laboratory, Madison, WI, USA.

Kusumah, S. S., Umemura, K., Yoshioka, K., Miyafuji, H., and Kanayama, K. (2016). "Utilization of sweet sorghum bagasse and citric acid for manufacturing of particleboard I: Effects of pre-drying treatment and citric acid content on the board properties," Ind. Crop. Prod. 84, 34-42. DOI: 10.1016/j.indcrop.2016.01.042

Liimatainen, H., Visanko, M., Sirviö, J. A., Hormi, O. E. O., and Niinimaki, J. (2012). "Enhancement of the nanofibrillation of wood cellulose through sequential periodatechlorite oxidation," Biomacromolecules 13(5), 1592-1597. DOI:

$10.1021 / \mathrm{bm} 300319 \mathrm{~m}$

Ma, X., Chang, P. R., Yu, J., and Stumborg, M. (2009). "Properties of biodegradable citric acid-modified granular starch/thermoplastic pea starch composites," Carbohyd. Polym. 75(1), 1-8. DOI: 10.1016/j.carbpol.2008.05.020

McNatt, J. D. (1974). Properties of Particleboards at Various Humidity Conditions, U.S. Department of Agriculture Forest Products Laboratory, Madison, WI, USA.

Muyonga, J. H., Cole, C. G. B., and Duodu, K. G. (2004). "Fourier transform infrared (FTIR) spectroscopic study of acid soluble collagen and gelatin from skins and bones of young and adult Nile perch (Lates niloticus)," Food Chem. 86(3), 325-332. DOI: 10.1016/j.foodchem.2003.09.038

Pizzi, A., and Mittal, K. L. (2003). Handbook of Adhesive Technology, Revised and Expanded, Marcel Dekker, Inc., New York, NY, USA.

Podschun, J., Stücker, A., Buchholz, R. I., Heitmann, M., Schreiber, A., Saake, B., and Lehnen, R. (2016). "Phenolated lignins as reactive precursors in wood veneer and particleboard adhesion," Ind. Eng. Chem. Res. 55(18), 5231-5237. DOI: 10.1021/acs.iecr.6b00594

Reddy, N., and Yang, Y. (2010). "Citric acid cross-linking of starch films," Food Chem. 118(3), 702-711. DOI: 10.1016/j.foodchem.2009.05.050

Robyt, J. F. (2008). "Starch: Structure, properties, chemistry and enzymology," in: Glycoscience, B. O. Fraser-Reid, K. Tatsuka, and J. Thiem (eds.), Springer-Verlag Berlin Heidelberg, Berlin, Germany, pp. 1437-1472. DOI: 10.1007/978-3-540-304296_35

Selamat, M. E., Sulaiman, O., Hashim, R., Hiziroglu, S., Nadhari, W. N. A. W., Sulaiman, N. S., and Razali, M. Z. (2014). "Measurement of some particleboard properties bonded with modified carboxymethyl starch of oil palm trunk," Measurement 53, 251-259. DOI: 10.1016/j.measurement.2014.04.001

Sulaiman, N. S., Hashim, R., Hiziroglu, S., Amini, M. H. M., Sulaiman, O., and Ezwanselamat, M. (2016). "Rubberwood particleboard manufactured using 
epichlorohydrin-modified rice starch as a binder," Cell. Chem. Technol. 50(2), 329338.

Sulaiman, N. S., Hashim, R., Mohamad Amini, M. H., Sulaiman, O., and Hiziroglu, S. (2012). "Evaluation of the properties of particleboard made using oil palm starch modified with epichlorohydrin," BioResources 8(1), 283-301.

DOI: 10.15376/biores.8.1.283-301

Sulaiman, N. S., Hashim, R., Sulaiman, O., Nasir, M., Amini, M. H. M., and Hiziroglu, S. (2018). "Partial replacement of urea-formaldehyde with modified oil palm starch based adhesive to fabricate particleboard," Int. J. Adhes. Adhes. 84, 1-8. DOI: 10.1016/j.ijadhadh.2018.02.002

Widyorini, R., Umemura, K., Isnan, R., Putra, D. R., Awaludin, A., and Prayitno, T. A. (2016). "Manufacture and properties of citric acid-bonded particleboard made from bamboo materials," Eur. J. Wood Wood Prod. 74(1), 57-65. DOI: 10.1007/s00107015-0967-0

Wilpiszewska, K., and Czech, Z. (2014). "Citric acid modified potato starch films containing microcrystalline cellulose reinforcement - properties and application," Starch 66(7-8), 660-667. DOI: 10.1002/star.201300093

Xi, X., Wu, Z., Pizzi, A., Gerardin, C., Lei, H., Zhang, B., and Du, G. (2019). "Nonisocyanate polyurethane adhesive from sucrose used for particleboard," Wood Sci. Technol. 53(2), 393-405. DOI: 10.1007/s00226-019-01083-2

Zhao, J., Yang, Y., Yu, M., Yao, K., Luo, X., Qi, H., Zhang, G., and Luo, Y. (2018). "Lanostane-type $\mathrm{C}_{31}$ triterpenoid derivatives from the fruiting bodies of cultivated Fomitopsis palustris," Phytochemistry 152, 10-21. DOI:

10.1016/j.phytochem.2018.04.012

Article submitted: December 19, 2019; Peer review completed: March 13, 2020; Revised version received and accepted: April 14, 2020; Published: April 15, 2020.

DOI: $10.15376 /$ biores.15.2.4234-4248 